\title{
Distant Echoes: Discussing Judicial Activism at Canadian and American Supreme Court Nomination Hearings
}

\section{Oliver Fitzgerald}

Marc Nadon was never drafted by the Detroit Red Wings. Media outlets pronounced this verdict during the week that the Supreme Court of Canada nominee answered questions from parliamentarians for three hours. ${ }^{1}$ After a hearing that covered Nadon's legal background, his views on the state of the legal profession, and his attitude towards judging, Canadians were asked to consider only why a judge would embellish his amateur hockey record when he was being nominated for a justiceship in the highest court in the land. Overlooked amidst this minor uproar were Nadon's relatively extensive comments on the Supreme Court's role and its relationship with Parliament. After the Court found Justice Nadon ineligible to sit on the Court, ${ }^{2}$ any hope that his comments would be examined in greater depth was extinguished.

This is surprising and disappointing. Canadian legal academics, commentators, and engaged citizens have expressed strong concerns that the judiciary, particularly the Supreme Court, frequently intrudes on Parliament's lawmaking role. Many have referred to this intrusion sweepingly as "judicial activism." Yet, despite these concerns, discussion of this topic has been scant during televised Supreme Court nominee hearings. The televised hearings were meant to be a forum to "promote public knowledge of the judges of the Court." 3 But on this salient topic, the hearings have failed: the public has gained very little knowledge of the judges' views on judicial activism. Unlike in the United States, the
Canadian judges and legislators whose actions drive this topic have mentioned it only cursorily when the country is paying the most attention.

This reticence is what makes Nadon's remarks so striking. His comments are the lengthiest, most detailed, and thought-provoking exposition a Supreme Court of Canada nominee has yet given on judicial activism; they signify the nomination process' subtle but discernable shift towards mimicry of the longstanding American Supreme Court confirmation hearings' preoccupation with this topic

This paper begins by tracing Canadians' concerns about judicial activism. Part II surveys how academics, commentators, and others have reacted to perceived overreaches by Canada's highest court over time. By evaluating the comments made by Justices Marshall Rothstein, Michael Moldaver, Andromache Karakatsanis, and Richard Wagner at their nominee hearings, Part III shows the paucity of official public discussion on the topic. Changing countries, Part IV explains how judicial activism has been canvassed recently in American Supreme Court nomination hearings; this part assesses how the topic has been addressed during and since Chief Justice John Roberts's confirmation hearing in 2005. Part V analyzes Justice Nadon's comments and demonstrates how they depart from Canadian precedent and towards a deeper, more American focus on the topic's vagaries. Part VI concludes with some thoughts on what Nadon's 
comments may portend should televised ad hoc committee hearings for Supreme Court nominees be restarted.

\section{Part II: Judicial Activism in Canada}

Canadian concerns about judicial activism have a long history and persist today. Some academics and commentators commend the Court for its activism while many condemn it. Indeed, even the definition of "judicial activism" is contested. Sujit Choudhry and Claire E. Hunter characterize it as "the more frequently [the Supreme Court] find [s] that democratically elected institutions have acted unconstitutionally." 4 Partly in response to Choudhry and Hunter, Christopher P. Manfredi defines it more precisely as "the willingness of courts to reverse or otherwise alter the policy decisions of legislatures and executives." Kent Roach's "four dimensions" of judicial activism are the most inclusive and will be short-handed by the phrase "judicial activism" for the remainder of this paper. ${ }^{6}$ Roach's first dimension is "the degree to which judges are free to read their own preferences into law when interpreting the constitution."7 The second is "the degree to which judges are eager to make constitutional judgments not necessary to decide a live dispute." 8 The third dimension is how judges recognize other social interests and whether individual rights trump them..$^{9}$ Roach's final dimension is the extent to which a court's decision displaces a law and whether this is the "final word" on the matter. ${ }^{10}$ These dimensions reflect how the phrase "judicial activism" has been used by Canadian parliamentarians, United States senators, and Supreme Court nominees.

Canadian unease about judicial activism is not a recent phenomenon. The Judicial Committee of the Privy Council represented the initial focal point for concerns that judges were intervening in the country's legislative affairs. That body's federalism decisions frequently frustrated Parliament's ability to direct Canada's national affairs. One academic claimed that the JCPC had "erected a judicial barrier to progressive change." ${ }^{11}$ Another opined that "None but foreign judges ignorant of the Canadian environment and none too well versed in Canadian constitu- tional law could have caused this constitutional revolution." 12 The JCPC made the "corner stone" out of what the Fathers of Confederation had rejected in federal-provincial power-sharing. ${ }^{13}$

However, the current and more relevant concerns about judicial activism arose alongside the revolution in individual and equality rights after the adoption of the Canadian Charter of Rights and Freedoms. The Supreme Court's purposive approach to the Charter combined with its reliance on Lord Sankey's "living tree" metaphor alarmed politicians, legal scholars, and media commentators. Peter H. Russell recalls the "spectre of unelected judges" overruling legislatures as the "most widespread democratic concern about the Charter" before and after its adoption. ${ }^{14}$ Another academic feared that the Charter had abrogated to the judiciary matters best left to the legislative and executive branches as Canada's "social arbitrator." 15

These concerns receded for a few years but returned in the late 1990s and early 2000s guided by the Reform Party of Canada and its successor, the Canadian Alliance. These politicians were assisted by the National Post who, one contemporary commentator wrote, had "declare[d] a public-relations war on the Court" because of the high percentage of laws it had overturned. ${ }^{16}$ The Same-Sex Marriage Reference ${ }^{17}$ was the high point of anxiety about judicial activism. One opponent of the decision claimed that two of the Court's justices, both "strong advocates of homosexual rights," believed that "the courts must take the lead on same-sex issues because of the failure of the political process to do so."18 Legal academics also entered the fray. One law professor exclaimed that the Court had asserted its "ownership of" marriage "by mere fiat"; the social interest in the practices and institution of marriage was subordinated to this new jurisdiction. ${ }^{19}$

This apprehension diminished in the latter half of the decade. Commentators focused on the novel televised hearings for Supreme Court nominees, or their absence, in the case of Justice Thomas Cromwell. One lawyer observed in 2010 that "When McLachlin became Chief Justice, there was a lot of criticism about judicial 
activism. You don't hear that debate so much anymore." 20 Indeed, whereas one commentator noted that the Court was being criticized for being too deferential towards the government, another considered the Court "too timid" towards legislatures. ${ }^{21}$

However, concerns re-emerged in the final years of Prime Minister Stephen Harper's government. On matters ranging from the constitutionality of physician-assisted suicide, to mandatory minimum sentences, to the determination of Justice Marc Nadon's eligibility to sit on the Supreme Court, commentators feared that the Court was overstepping its ambit. After the Court struck down laws against physician-assisted suicide, columnist Andrew Coyne described the Court as doing so "in breezy defiance [...] of Parliament's stated preferences [and] of the Court's own ruling in a similar case." 22 When the Court struck down a mandatory minimum sentence provision, the Conservative minister of justice bristled that the Court did so based on a "far-fetched hypothetical scenario." 23 After the Supreme Court found Justice Nadon ineligible to sit on its bench, one commentator wrote that "the current judges just didn't want this fellow in their midst." ${ }^{24} \mathrm{He}$ implored legislators to start having the final word and begin using the Charter's notwithstanding clause regularly. ${ }^{25}$

\section{Part III: Judicial Activism and Parliamentary Hearings for Nominees to the Supreme Court of Canada}

The longstanding concern about the Supreme Court of Canada's activism has not been reflected in the path-breaking televised nominee hearings. At these hearings, legislators have had the opportunity to put their queries to Court nominees and Canadians can watch the responses from those who will embody concerns about judicial activism: the future justices themselves. The history of these hearings is short. They began only in 2006 and have been used for only five of the last nine nominees. The hearings are not required by the constitution or by statute. Unlike in the United States, Canada's parliamentarians do not pos- sess an "Advice and Consent" duty to the executive branch for the country's judicial nominees. The result is that the hearings have not reflected the lengthy and nuanced discussions of judicial activism displayed by Canadian legal commentators and academics or found in US Supreme Court hearings.

Justice Marshall Rothstein's hearing in 2006 was promising. Rothstein received many questions about judicial activism and restraint. One academic noted Rothstein's "repeated and expressed approval for judicial restraint in constitutional review." ${ }^{26}$ However, his testimony did not reflect the topic's complexity. In his opening remarks, Rothstein assured parliamentarians that judges do not have "some kind of upper hand over Parliament or the legislatures." ${ }^{27} \mathrm{He}$ noted judges can depart from precedent, that they can evolve a law that "was clearly in error [. . . and when] intervening cases have attenuated the validity of a prior decision." ${ }^{28}$ Rothstein made clear that each branch of government had its assigned role to play and that the judiciary should be cautious when striking down a law passed by a democratically-elected legislature. The judiciary "must preserve the intent of the legislature or Parliament to the extent possible. The least intrusive approach must be adopted." ${ }^{29}$ Rothstein came closest to describing a personal judicial philosophy when he explained that his "cardinal rule" was not to read language into a law that Parliament did not include. ${ }^{30}$ Member of Parliament Real Menard opened and then closed a promising opportunity to explore Rothstein's judicial philosophy when he opined that "[Rothstein] would be more in favour of a more literal approach or reading of the law." ${ }^{31}$ But Menard moved swiftly to another topic, denying Rothstein the chance to respond to his interrogator's characterization of his views. Overall, Justice Rothstein's remarks on judicial activism and the role of the courts were standard fare for anyone broadly familiar with these topics. ${ }^{32}$

Justices Michael Moldaver and Andromache Karakatsanis' 2011 joint hearing failed to build on this meagre foundation. Both nominees discussed the topics less than Justice Rothstein, and in broader terms. Justice Moldaver emphasized 
familiar tropes such as respect for the judicial and legislative roles. He stated that:

Under the rule of law it is not our function to create laws, nor do we have the right to direct governments on matters of policy. Under the Constitution we have been given the authority to determine the legality of laws passed by Parliament and the legislatures. In fulfilling that role, we must never lose sight of the fact that we are being asked to strike down laws that have been enacted by a democratically elected majority of parliamentarians. ${ }^{33}$

This promising comment, which was unfortunately not further explored with follow-up questions, indicated Moldaver's belief in the judiciary acting as a barometer for the Canadian public's sensibilities. The nominee noted that:

\footnotetext{
The beauty of Canada, though, is that we are not a country of extremes. There are certain parameters within which we all act. There are certain things that are simply unacceptable to Canadians. If the law and order side goes beyond what the courts feel are the proper balance, then we have to send a message back to Parliament that you have gone too far. ${ }^{34}$
}

This remark was intriguing. That the Supreme Court determines what is acceptable for all Canadians ("we all") could indicate that the nominee viewed the Court as having a conscience-like function, one that passes beyond neutrality and strict application of the law and considers issues with community standards in mind. How would he reconcile this idea with his previous answer? Regrettably, because Justice Moldaver does not speak French, the next questioner chose to focus on unilingualism and not pursue this promising line of inquiry.

Justice Karakatsanis's answers to questions about judicial activism and the role of the Supreme Court were almost entirely perfunctory. When asked if the judicial role includes rewriting or reinventing laws, Karakatsanis replied that "It is not our job to create law but to apply it. It is your job to create law, that is the legislative power." ${ }^{35}$ The nominee seemed to foreshadow Justice Moldaver's comments about the Court as Canada's conscience. Karakatsanis stated that judges "must embody and protect the fundamental values of our Canadian community in accordance with our Canadian Charter of Rights and Freedoms." ${ }^{36}$ However, no subsequent question allowed for any elaboration of how judges "embody" those "fundamental values," what the nominee believed those "fundamental values" were and what she meant by "Canadian community." After her hearing, Canadians were certain only that Justice Karakatsanis believed in the familiar notion that judges should reflect evolutionary change in their decisions but that "radical" change should be left to Parliament. ${ }^{37}$

Richard Wagner's 2012 hearing was a sorely missed opportunity. The hearing began promisingly enough with the opening remarks of Justice Jean-Louis Beaudoin, who Parliament requested to describe the hearing's "constitutional framework." 38 Beaudoin seemingly wanted to incite a debate about judicial activism between the legislators and the nominee, declaring:

\begin{abstract}
"The court actually is the final bastion of our collective and individual freedoms. It is the final defender of human rights and the body that ultimately gives appropriate meaning to the Charter. In a democracy like ours, this is a particularly delicate mission. In the absence of precise legislation, the court must fill voids in and find solutions to extremely complex matters that those who come before it bring because our society is constantly evolving [emphasis added]. ${ }^{39}$
\end{abstract}

The statement seemed designed to begin a charged discussion on different theories of the judiciary's role in government. If that was Justice Beaudoin's hope, he was likely disappointed by what followed.

Justice Wagner's testimony was the nadir of these hearings' discussions of judicial activism. Wagner paid tribute to judicial restraint by saying "The courts must apply the law. It is up to parliamentarians to enact legislation and it is not up to the courts to do it for them." ${ }^{40} \mathrm{He}$ explained that alongside the proper judicial role, judges must account for changes in society: "Society evolves, as does the role of judges in society. But it is important that they be able to participate in this evolution, to describe their work and speak about the justice system, all while taking 
into account their judicial restraint." ${ }^{41}$ When Conservative Scott Reid asked Wagner the bestresearched question about judicial activism yet ventured since these hearings began, ${ }^{42}$ Wagner demurred, stating that "It is quite possible - not possible, but probable - that the Supreme Court will be called again to interpret the Constitution, and with all due respect, I would like to be part of that debate and that decision. I would prefer not to comment on this question at this time." ${ }^{33}$ When Reid sought an answer to the same question in a subsequent round using another wellresearched prompt, ${ }^{44}$ Wagner again declined to answer. Justice Wagner's hearing is remarkable for how little Canadians learned about the nominee's views on judicial activism despite wellcrafted attempts to do so.

For Canadians seeking to learn what Supreme Court justices think about their role and the Court's relationship with Parliament, the first three televised nominee hearings were a disappointment. They touched on these topics only broadly and follow-up questions to intriguing answers were not made. These hearings were a pale imitation of the discussions that occur in the United States.

\section{Part IV: Judicial Activism and Confirmation Hearings for Nominees to the United States Supreme Court since 2005}

United States senators do not tarry in asking nominees to the US Supreme Court about their views on judicial activism. The subject is well canvassed after a months-long process that begins with the president's nomination and ends with the Senate's vote on whether to confirm the nominee. A nominee meets with senators after the president nominates him or her. He or she completes questionnaires prepared by the Senate Judiciary Committee. Recently, nominees have endured so-called "murder boards," or mock hearings where the nominee faces off against Justice Department staffers playing the roles of individual senators on the Committee. ${ }^{45}$ Throughout the hearing (which consists of senators' and the nominees' opening statements, the senators' questions, the nominees' answers, and witness testimony), judicial activism is discussed at great length and variety. One study found that since nominee hearings were opened to the public, $12.4 \%$ of nominees and senators' comments were about "judicial philosophy," the third most discussed topic, behind only "chatter" and "civil rights." 46 A result of this entire process is a deep understanding of the nominee's attitude towards judicial activism, an understanding shared by senators, the media and the American people. Indeed, this aspect can be the lasting memory of the nomination: Chief Justice John Roberts' characterization of a judge as an "umpire" who calls "balls and strikes" is still mentioned frequently.

While Republican senators have asked more questions overall about "judicial philosophy," ${ }^{47}$ senators from both parties display similar levels of concern when the nominee is made by a president from the other party. Since 2005, three candidates have been nominated by a Republican president, George W. Bush, ${ }^{48}$ and two candidates have been nominated by a Democratic president, Barack Obama. Neither party's senators have given a candidate from the opposing party's president an easy time answering questions about judicial activism. Yet, senators from the nominating president's party are equally concerned about a nominee's views. Nominees appear to be just as preoccupied with allaying senators' concerns as the senators are about voicing them. Questions about substantive policy, separate from those explicitly about judicial activism, tend to circle back to a focus on the Court and judges' roles within government. A small selection of the diverse ways in which discussion of judicial activism surfaces in these hearings demonstrates the attention the topic receives.

Chief Justice Roberts' confirmation hearing in 2005 is very illustrative. Nominated by President Bush, Roberts endured extensive questioning from both Democratic and Republican senators. His answers were lengthy and complex. On his questionnaire, he demonstrated his knowledge of judicial activism's dimensions. Roberts expressed concern about the judiciary "[imposing] broad, affirmative duties upon governments 
and society." ${ }^{49}$ The judiciary should be wary of using a plaintiff as a "vehicle" to impose "farreaching orders extending to broad classes of individuals." ${ }^{50} \mathrm{He}$ was forthcoming at the hearing, too. Responding to Democrat Charles Schumer's question on privacy rights, Roberts stated that judges "need to [have] an appropriate sensitivity to the limitations on the judicial role. Again, you need to recognize that it is not your job to make policy, either under the Constitution or under the statutes. You are interpreting the Constitution." ${ }^{51}$ In response to Republican Charles Grassley's query on his view of Court-created solutions that are required when other branches of government fail to act, Roberts stated "it is not the job of the Court to solve society's problems [. ..]. It is the job of the Court to decide particular cases." ${ }^{2}$ Occasionally, Congress fails intentionally to answer a question and the Court should not step in to address it. ${ }^{53}$ Indeed, when Roberts was asked about his mentorship by Chief Justice William Rehnquist, the nominee turned his response into a discussion of the importance of "the appropriate limits on the judicial role and judicial power" and "judicial self-restraint." ${ }^{4}$

Samuel Alito echoed Roberts's emphasis on the importance of judicial restraint loudly. The nominee went to even greater lengths to assure senators that the Supreme Court's role should be a minimal one. To a question about the reapportionment of voting districts, Alito discussed his "strong belief in judicial self-restraint" and its origins in a book by Alexander Bickel. ${ }^{55}$ When another senator asked about a decision Alito wrote on a lower court, Alito explained and contextualized his belief that judges should not decide issues "that don't have to be decided." 56 When Senator Grassley queried again about a hypothetical "certain area" in which Congress "had not even acted" and asked whether Alito would consider "fill[ing] in on something that Congress didn't do," Alito interrupted Grassley. He asserted that "The judiciary is not a law-making body. Congress is the law-making body. Congress has the legislative power and the judiciary has to perform its role and not try to perform the role of Congress or the Executive." ${ }^{57}$ Indeed, when asked why he wanted to be a Supreme Court justice, Alito's answer indicated in part that he wanted the office to serve as a check on judicial power, to be part of the Court's "own discipline" and be "constantly monitoring its own activities." 58

Justice Sonia Sotomayor's hearing was partly overshadowed by past comments she had made. In speeches given years before her nomination, Justice Sotomayor appeared to imply that being a "wise Latina" prepared her better to decide certain cases. Republicans did not hesitate to voice their anxiety about these comments. Senator Jeff Sessions asked about the quote and Justice Sotomayor strived to reassure him that she believed "that judges should not be using their personal biases, their personal experiences, their personal prejudices in reaching decision [sic]." ${ }^{\prime 9}$ Asked about a 1992 questionnaire she completed upon being nominated to a lower court, Sotomayor explained her belief that the judiciary should interpret unconstitutional provisions in a law narrowly so as to preserve the rest of the law and, in so doing, Congress' intent. ${ }^{60}$ When asked which Supreme Court judge she admired, Sotomayor answered "Justice [Benjamin] Cardozo" because of "his great respect for precedent, and his great respect for respect and deference $[$ sic] to the legislative branch, and to the other branches of government and their powers under the Constitution." ${ }^{61}$ To Republican John Cornyn's question of "Do you believe that judges ever change the laws?" Sotomayor responded

"We're not lawmakers. But we change our view
of how to interpret certain laws based on new
facts, new developments of doctrinal theory,
considerations of whether - what the reliance
of society may be in an old rule. We think about
whether a rule of law has proven workable." ${ }^{62}$

A question from Democrat Al Franken regarding age discrimination legislation turned into a discussion of a court's right to decide an argument not advanced by a litigant. ${ }^{63}$ To a question about Second Amendment rights, Sotomayor stated that "Well, you hire judges for their judgment, not their personal views or what their sense of what the outcome should be. You hire your point judges for the purpose of understanding whether they respect law, whether they respect precedent and apply it." ${ }^{64}$ Justice Sotomayor's answers dis- 
tinguished from the emphasis Roberts and Alito placed on judicial restraint. Sotomayor acknowledged tacitly the role a judge's unique reasoning and judgment can have on a case's outcome. This was an interesting change of tone from previous hearings, a change that received persistent attention during the hearings.

Elena Kagan's confirmation hearing marked a shift back towards Roberts' and Alito's emphasis on judicial restraint. Kagan asserted that “judges can't import their own personal preferences or their political preferences or their moral values, [...] it would be inappropriate to do so." ${ }^{65}$ In an exchange with Republican Lindsay Graham about Israeli Justice Aharon Barak, described by Graham as an "activist judge," Kagan asserted that it was "wrong" that a "Court can change a statute." ${ }^{66}$ Kagan discussed why an activist judiciary is possible in Israel given that country's unwritten constitution. ${ }^{67}$ She explained that judicial activism has no political ideology or party; it is not, but can be both, liberal or conservative. ${ }^{68}$ To a question about expanding the Fourteenth Amendment to include substantive freedoms, Kagan noted that the Court "should act in this area with appropriate caution and respect for democracy." ${ }^{69}$ Justice Kagan's confirmation hearing brought the discussion about judicial activism and the Court's role back to a defence of judicial restraint more in line with Roberts' and Alito's hearings.

As this section has made quite clear, concerns in the United States about judicial activism are aired loudly during confirmation hearings of Supreme Court nominees. They surface in questions and answers about different areas of the law. They also emerge explicitly. They are not confined to one party and are directed at nominees made by presidents from both parties. Occasionally, the nominees' answers give the impression that they are absolute in their views. However, they modify this perception elsewhere in their testimony while demonstrating their views' sound, intellectual underpinnings. Throughout, they bolster their views with discussions of jurisprudence, theory, and history. The result is a clear and detailed idea of how the particular nominee views judicial activism.

\section{Part V: Justice Marc Nadon's Comments on Judicial Activism}

Justice Marc Nadon's comments on judicial activism at his 2013 nomination temporarily ended the Canadian trend of vague, platitudinal comments on the topic. In so doing, they sounded as if they might have come from a US Supreme Court confirmation hearing. Nadon spoke at greater length on judicial activism than any nominee since Justice Rothstein and articulated a deeper understanding of and insight into the nuances of the topic. He moved beyond familiar tropes such as the proper roles of the judiciary and the legislature and into the history and theory that underpins them.

True to form, Justice Jean-Louis Beaudoin seemed intent on galvanizing a discussion. He succeeded this time. Beaudoin noted first that because the Charter is written in "general terms," the Supreme Court "[binds] legal substance to a series of general notions, such as 'free and democratic society." 70 This substance changes over time and "requires the new justice, as well as all of the court's justices, to have the ability to adapt to a changing society." ${ }^{\prime 1}$ Beaudoin asserted, somewhat contradictorily, that

"[. . .] the legislative authority is paramount in a democratic society. The Supreme Court, however, has the mission of aligning the fundamental freedoms recognized under the [Charter] with the sociological and political changes of Canadian society as a whole. In that sense, the court's job is to bring about progress in the law." ${ }^{.72}$

Nadon took his cue from Beaudoin. Whereas previous nominees made a point of affirming their belief that the judiciary should not infringe on the legislative domain, Nadon approached this topic from the opposite side. He noted that the judiciary is "very protective of its jurisdiction and of its role in society." ${ }^{33}$ The judiciary sits in judgement of the executive: the judiciary "routinely review[s] the executive's actions." ${ }^{74}$ Nadon added later that "the [Charter] requires courts to interfere somewhat and tell Parliament that what it did is unacceptable and that it has to redo it." ${ }^{75}$ This point was not novel. But in the context 
of these hearings, it marked a decisive shift in tone. Other nominees went out of their way to assure parliamentarians that the Court should not intrude on the legislative branch's role. Nadon seemed to proudly defend the judiciary's duty to ensure the constitutionality of the other branches' actions. Nadon spoke of the different "tools" legislators and judges use to "achieve justice." ${ }^{76}$ He prized judicial review to an extent not witnessed by the justices that came before him. Further questioning of these views would have been illuminating. To what extent should a court "interfere" and tell Parliament to "redo" a law? How does the judiciary "achieve justice"? Despite this missed opportunity, Nadon's answers were refreshing nevertheless.

Justice Nadon placed the judiciary's duty to strike down unconstitutional laws in a historical context. He discussed how the American Founding Fathers, influenced by the Federalist Papers, situated the judiciary within their government. Nadon observed that the judiciary's duty was previously only to apply the law; it embodied the Madisonian concept of "the least offensive branch" because it did not intrude into the lives of citizens. ${ }^{77}$ Now, Nadon explained, some scholars call the judiciary the "most dangerous branch" because they "feel that courts go too far." ${ }^{78}$ This fear is especially pronounced for Canadians in the wake of the Charter. Before 1982-1985, a court "had to apply [the law], end of story." ${ }^{79}$ The Charter creates "the exception" to the Court's usual function. Now, the Court determines whether a law creates discrimination, whether it infringes Canadians' lives and freedoms: "Like relay runners, the courts have grabbed the baton and have studied all these major issues since 1982 , and especially since 1985."

While this discussion of judicial activism may appear trite to academics and commentators more familiar with the subject's nuances, the comments demonstrated sophistication no doubt possessed - but not previously displayed - by past Supreme Court nominees. Nadon delved deeper into the matter of judicial activism than any of his predecessors. His testimony revealed a judge at ease with striking down laws, an image that was perhaps surprising given the prime minister who nominated him. The testimony also served as a useful primer for Canadians only vaguely familiar with the concept of judicial activism. More importantly, this discussion came from the "horse's mouth." It was between a member about to ascend to the Supreme Court, albeit briefly, and the legislators whose laws he would review. Although Nadon's comments only inched towards the depth and ubiquity displayed in US Supreme Court nominee hearings, his testimony represented a new departure nevertheless. If his comments were only an echo, they were a loud one. They deserved more attention than they received.

\section{Part VI: Conclusion}

For Canadians seeking information about Supreme Court justices' views on judicial activism, the televised nominee hearings have been largely disappointing. With the exception of Justices Marc Nadon and, arguably, Marshall Rothstein, judicial activism has gone largely unexamined. This is surprising for a few reasons. First, as demonstrated by the reactions to many Supreme Court decisions, a Canadian appetite for this discussion clearly exists. Canadian legal academics, commentators, and other engaged citizens have not hesitated to voice their concerns - some better defined than others about a Court they perceive to be overreaching. While this appetite does not rival the corresponding well-fed American hunger, its recurrence through constitutional changes, different jurisprudential eras, governments, and court compositions demonstrates its endurance. Both legislators and nominees have shown a desire to discuss judicial activism during these hearings. Parliamentarians have asked nuanced and detailed questions. Nominees have answered likewise. That Nadon's comments went unanalyzed is disappointing. But the comments themselves are welcome developments that can be improved upon. Whether or not they will be remains an open question.

Just as important: since Nadon's hearing, no Supreme Court nominees have appeared before any parliamentary committee, televised or otherwise. Justices Clement Gascon, Suzanne Cote, 
and Russell Brown were appointed to the Court without answering any questions from legislators. Prime Minister Justin Trudeau's new government has trumpeted its ambition to be more transparent. This openness could extend to the appointment of Supreme Court justices. While restarting televised parliamentary hearings would be beneficial, pushing outward from the strictures imposed on them would be better still. Professor Peter Hogg's warning that these hearings should neither "politicize the judiciary" nor "publicly embarrass" the nominees ought to be remembered. ${ }^{81}$ But Hogg's caution should not discourage parliamentarians from seeking more detailed explanations and asking follow-up questions about subjects as salient as judicial activism. The confirmation hearings of the past four United States Supreme Court nominees reveal that discussing the topic can be done without political fireworks. Inquisitive legislators and forthcoming nominees can have a sophisticated discussion. Even if the questions go unanswered, as in Justice Wagner's hearing, posing them at least channels the Canadians these legislators represent.

Justice Nadon's comments give hope that these questions can be satisfactorily asked and answered. They were only slightly steeped in the history, jurisprudence and philosophy displayed in American hearings. But, nevertheless, his comments demonstrate an evolution from the staid, vague, and familiar testimony given by those who preceded him. For Canadians with the hope that televised nominee hearings will open the Supreme Court up further, this may be promise enough that greater transparency can follow.

\section{Endnotes}

1 For example, see Tonda MacCharles, "Supreme Court Justice Marc Nadon feels a draft after hockey claim whistled down", The Toronto Star (3 October 2013), online: <http://www.thestar.com/news/ canada/2013/10/03/marc_nadon_confirmed_as_ justice_of_the_supreme_court_of_canada.html $>$.

2 Reference re Supreme Court Act ss 5 and 6, 2014 SCC 21, [2014] 1 SCR 433.
3 Peter W Hogg, "Appointment of Justice Marshall Rothstein to the Supreme Court of Canada" (2006) 44:3 Osgoode Hall LJ 527 at 537 [Hogg].

4 Sujit Choudhry \& Claire E. Hunter, "Measuring Judicial Activism on the Supreme Court of Canada: A Comment on Newfoundland (Treasury Board) v. NAPE” (2003) 48 McGill LJ 525 at 532.

5 Christopher P. Manfredi, "Judicial Power and the Charter: Reflections on the Activism Debate" (2004) 53 UNBLJ 185 at 188.

6 Kent Roach, The Supreme Court on Trial: Judicial Activism or Democratic Dialogue (Toronto: Irwin Law, 2001) at 106-10.

7 Ibid at 106.

8 Ibid.

9 Ibid.

10 Ibid.

11 Raphael Tuck, "Canada and the Judicial Committee of the Privy Council” (1941) 4:1 UTLJ 33 at 71.

12 F R Scott, "The Consequences of the Privy Council Decisions" (1937) 15:6 Can Bar Rev 485 at 489.

13 Ibid.

14 Peter H. Russell, "The Charter and Canadian Democracy" in James B. Kelly \& Christopher P. Manfredi, eds, Contested Constitutionalism: Reflections on the Canadian Charter of Rights and Freedoms (Vancouver: UBC Press, 2009) 287 at 290.

15 Sebastien Lebel-Grenier, "The Charter and Legitimization of Judicial Activism" in Paul Howe \& Peter H. Russell, eds, Judicial Power and Canadian Democracy (Montreal \& Kingston: McGill \& Queens University Press, 2001) 94 at 97.

16 Susan Delacourt, "The Media and the Supreme Court of Canada" in Hugh Mellon \& Martin Westmacott, eds, Political Dispute and Judicial Review: Assessing the Work of the Supreme Court of Canada (Scarborough: Nelson, 2000) 31 at 36.

17 Reference re Same-Sex Marriage, 2004 SCC 79, [2004] 3 SCR 698.

18 C Gwendolyn Landolt, "Don't let them fool you: A small group of elites is forcing a redefinition of marriage in Canada", Ottawa Citizen (17 December 2004).

19 F. C. DeCoste, "Courting Leviathan: Limited Government and Social Freedom in Reference Re Same-Sex Marriage" (2005) 42:4 Alta L Rev 1099 at 1103 .

20 Yves Faguy, "Peace in the Family", National [June 2010] 14 at 18. The lawyer was Mahmud Jamal.

21 Ibid at 18.

22 Andrew Coyne, "Supreme Court euthanasia ruling marks the death of judicial restraint", National Post (13 February 2015), online: <http://news. 
nationalpost.com/full-comment/andrew-coynesupreme-court-euthanasia-ruling-marks-thedeath-of-judicial-restraint $>$.

23 Peter Mackay, "What the Court got right - and wrong - on mandatory sentences for gun crimes", National Post (21 April 2015), online: <http:// news.nationalpost.com/full-comment/petermackay-what-the-court-got-right-and-wrong-onmandatory-sentences-for-gun-crimes $>$.

24 Gordon Gibson, "Who is judging the judges?", The Globe and Mail (19 February 2015), online: $<$ http://www.theglobeandmail.com/opinion/whois-judging-the-judges/article23069380/>.

25 Ibid.

26 Carissima Mathen, "Choices and Controversy: Judicial Appointments in Canada" (2008) 58 UNBLJ 52 at 70.

27 Parliament of Canada, Opening Remarks by Mr. Justice Marshall Rothstein to Ad Hoc Committee to Review a Nominee for the Supreme Court of Canada, February 27, 2006 (26 February 2006), online: <http://www.collectionscanada.gc.ca/ webarchives/20071125225909/http://www.justice. gc.ca/en/news/sp/2006/doc_31794.html>.

28 Ibid.

29 Ibid.

30 CPAC, "Ad Hoc Committee Review of the nomination of Justice Marshall Rothstein, for the Supreme Court of Canada, February 27, 2006", online: <http://www.cpac.ca/en/digitalarchives/?search $=$ rothstein $>$.

31 Ibid.

32 After Rothstein retired from the Supreme Court in 2015 he gave a speech at the University of Saskatchewan where he spoke at length on judicial activism. See Michael Plaxton, "Rothstein on Judicial Activism", Policy Options (14 October 2015), online: <http://policyoptions.irpp. org/2015/10/14/rothstein-on-judicial-activism/>.

33 Parliament of Canada, Ad Hoc Committee on the Appointment of Supreme Court of Canada Justices (19 October 2011), at 1615, online: http:// www.justice.gc.ca/eng/news-nouv/ja-nj/2011/ doc_32665.html>.

$34 \mathrm{Ibid}$ at 1830.

$35 \mathrm{Ibid}$ at 1800.

36 Ibid at 1635.

37 Ibid at 1755.

38 Parliament of Canada, Ad Hoc Committee on the Appointment of Supreme Court of Canada Justices (4 October 2012), at 1530, online: <http:// www.justice.gc.ca/eng/news-nouv/ja-nj/2012/ doc_32800.html>.

39 Ibid at 1535.
40 Ibid at 1640.

$41 \quad$ Ibid at 1645.

42 Ibid at 1655 . The question is worth reproducing because of its sophistication:

"Eighty years ago, in the famous Persons case, Lord Sankey wrote what I think is the best known piece of obiter in Canadian jurisprudence when he said, "The British North America Act planted in Canada a living tree capable of growth and expansion within its natural limits." This is often taken to mean that the courts can and should alter the meaning of parts of the Constitution, so as to allow it, as one court has said, to accommodate the realities of modern life. Until recently, the courts took a very different view. For example, I have a quote here from a 1937 ruling of the Alberta Court of King's Bench, in which the judge ruled: "It seems to me that none of the observations of Viscount Sankey can be said to provide legal justification for an attempt by Canadian Courts to mould and fashion the Canadian Constitution by judicial legislation so as to make it conform according to their views to the requirements of present day social and economic conditions." I'd be interested in your views on this subject.

43 Ibid at 1700.

$44 \mathrm{Ibid}$ at 1740. Again, because of Reid's appreciation for judicial history, the question is reproduced:

"About 30 years ago, prior to the charter [sic] actually, when he was dealing with a question relating to the division of powers, the then Chief Justice Dickson stated: If the Canadian Constitution is to be regarded as a "living tree" and legislative competence as "essentially dynamic", then the determination of categories - by which I think he means "heads of power" - existing in 1867 becomes of little, other than historic, concern. In other words, he was looking at the possibility that the courts could, in order to achieve a more effective federation, adjust the legislative competence of the federal and provincial legislatures. I wonder how you feel about that approach."

45 David Schneiderman, Red, White, and Kind of Blue?: The Conservatives and the Americanization of Canadian Constitutional Culture (Buffalo, NY: University of Toronto Press, 2015) at 255.

46 Lori A. Ringhand and Paul M. Collins Jr, "May It Please the Senate: An Empirical Analysis of the Senate Judiciary Committee Hearings of Supreme Court Nominees, 1939-2009" (2011) 60:3 Am U L Rev 598 at 617-18. 
47 Ibid at $623,626$.

48 President Bush nominated Harriet Miers before Samuel Alito but Miers withdrew her nomination before she appeared at the Senate Judiciary Committee's public hearing. Miers' nomination ordeal is not covered in this paper.

49 US, Confirmation Hearing on the Nomination of John G Roberts, Jr to be Chief Justice of the United States: Hearing Before the Committee on the Judiciary United States Senate, 109th Cong (2005) at 121 .

50 Ibid.

51 Ibid at 259.

52 Ibid at 178 .

53 Ibid at 179.

54 Ibid at 292.

55 US, Confirmation Hearing on the Nomination of Samuel A Alito, Jr to be an Associate Justice of the Supreme Court of the United States: Hearing Before the Committee on the Judiciary United States Senate, 109th Cong (2006) at 519-20.

$56 \mathrm{Ibid}$ at 343. Alito referred to Justice Louis Brandeis' decision in Ashwander $v$ Tennessee Valley Authority in framing his answer on the doctrine of constitutional avoidance.

57 Ibid at 356

58 Ibid at 474.

59 US, Confirmation Hearing on the Nomination of Hon Sonia Sotomayor, to be an Associate Justice of the Supreme Court of the United States: Hearing Before the Committee on the Judiciary United States Senate, 111th Cong (2009) at 392.
60 Ibid at 407.

61 Ibid at 79.

62 Ibid at 329.

63 Ibid at 385-86.

64 Ibid at 424.

65 US, The Nomination of Elena Kagan to be an Associate Justice of the Supreme Court of the United States: Hearing Before the Committee on the Judiciary United States Senate, 111th Cong (2010) at 172.

$66 \quad$ Ibid at 267.

67 Ibid at 130.

68 Ibid at 151.

69 Ibid at 272.

70 Parliament of Canada, Ad Hoc Committee on the Appointment of Supreme Court of Canada Justices (22 October 2013), at 1335, online: <http:// www.justice.gc.ca/eng/news-nouv/ja-nj/2013/ doc_32972.html>.

71 Ibid.

72 Ibid.

73 Ibid at 1410.

74 Ibid.

75 Ibid at 1510.

76 Ibid at 1410.

77 Ibid at 1415.

78 Ibid.

79 Ibid at 1425.

80 Ibid.

81 Hogg, supra note 3 at 537. 
